SŁAWOMIR KURSA

\title{
OCHRONA ORTODOKSYJNEJ WIARY W USTAWODAWSTWIE JUSTYNIANA
}

Ochrona ortodoksyjnej wiary, podobnie zresztą jak dbałość o jednolitość i trwałość państwa, należała do priorytetów w życiu i działalności cesarza Justyniana I. Jego polityka wyznaniowa na tle działań wcześniejszych cesarzy chrześcijańskich nie była jednak czymś nadzwyczajnym i odosobnionym. Niniejszy artykuł zmierza do wyjaśnienia tego, że była ona raczej wypadkową tendencji, które w obszarze prawnej ochrony religii chrześcijańskiej zaznaczyły się już w epoce pokonstantyńskiej i wykazania tego, że podobne też były środki, jakimi Justynian posługiwał się, by ją umocnić i przeciwstawić wciąż istniejącemu zjawisku herezji i apostazji.

1. Pozycja Prawna Kościola Katolickiego w CESARSTWIE RZYMSKim W VI W. N.E.

Jeszcze na początku IV wieku po Chrystusie pozycja prawna, która umożliwiałaby swobodny rozwój chrześcijaństwu, była wielce wątpliwa, chociaż wiara katolicka zakorzeniła się już w sercach wielu obywateli rzymskich. Przełomowe okazały się dwa cesarskie edykty: edykt tolerancyjny z 30 kwietnia 311 roku, wydany przez Galeriusza w Nikomedii, który przyzwolił na prowadzenie praktyk religijnych przez chrześcijan, oraz edykt mediolański Konstantyna I z 313 roku, który nadał chrześcijaństwu status religii o dozwolonym kulcie i swo- 
bodę wyboru religii. Ich skutkiem było wyjście chrześcijaństwa z katakumb i ujawnienie się w życiu publicznym, które okazało się na tyle powszechne i znaczące, że cesarz Teodozjusz I w edykcie Cunctos populos z 27 lutego 380 roku uznał je w wersji katolickiej za religię państwową, jedyną dla poddanych i jedynie prawdziwą, zaś wyznawców innych religii określał jako ludzi nierozumnych i szalonych ${ }^{1}$. Innymi słowy, mocą niniejszego edyktu cesarz Teodozjusz I uczynił państwo rzymskie państwem wyznaniowym w wersji zamkniętej.

Po rzeczonym edykcie pozycja starej religii pogańskiej stawała się coraz gorsza. Zakazywano jej praktyk, burzono lub zamykano świątynie pogańskie, często wykorzystując dalej jako budynki użyteczności publicznej albo oddając Kościołowi katolickiemu. Zmieniono kalendarz, zastępując święta pogańskie świętami chrześcijańskimi. Stopniowemu pogorszeniu ulegała także sytuacja judaizmu².

Cesarz Teodozjusz II dał szczególny wyraz chrześcijańskiej gorliwości w księdze szesnastej swojego kodeksu, którą w całości poświęcił sprawom religijnym. Z punktu widzenia niniejszego artykułu ważne są przede wszystkim jej tytuły: pierwszy De fide catholica, piąty De haereticis i siódmy De apostatis.

Podobnie, jak wspomniany poprzednik, także Justynian uczynił z prawa narzędzie umacniania pozycji Kościoła katolickiego w chylącym się ku upadkowi imperium. Dla podkreślenia, że stanowione przez niego normy prawne pozostają w zgodzie z prawem boskim, kontynuował w szczególności praktykę stosowania invocatio Dei w aktach

${ }^{1}$ C.Th. 16,1,2; szerzej na temat struktury tekstu edyktu, jego novum i konsekwencji wydania go zob. B. SiтeK, O edykcie Teodozjusza 'De fide catholica'. Krótkie uwagi o tolerancji i nietolerancji religijnej na przełomie IV $i \mathrm{~V}$ w. po Chr., [w:] 'Cuius regio eius religio'?, red. G. GóRSKI, L. ĆWIKŁA, M. LIPSKA, Lublin 2006, s. 13 i n.; por. także P.P. JoAnNou, La législation imperiale et la christianisation de l'Empire Romain (311-476), Rome 1972, s. 44.

${ }^{2}$ A. DĘBIŃski trafnie zauważa, że ustawy karne cesarza Teodozjusza II i Justyniana zawierały różne sankcje względem heretyków, apostatów, pogan, Żydów i manichejczyków, biorąc pod uwagę ich stosunek do religii państwowej i stopień szkodliwości społecznej, zob. TenżE, Przestępstwa religijne $w$ prawie rzymskim okresu późnego cesarstwa, [w:] 'Contra leges et bonos mores'. Przestępstwa obyczajowe w starożytnej Grecji i Rzymie, red. H. Kowalski, M. KurYŁowicz, Lublin 2005, s. 66. 
ustawodawczych $^{3}$, przykładowo Constitutio Imperatoriam z 21 listopada 533 roku, wprowadzająca w życie Instytucje, zawierała słowa in nomine Domini nostri Ihesu Christi, a księga pierwsza kodeksu cesarza z 534 roku, podobnie jak księga szesnasta Kodeksu Teodozjańskiego, poświęcona została sprawom religijnym, zaś jej pierwszy tytuł otrzymał znamienne brzmienie: De summa Trinitate et de fide catholica et ut nemo de ea publice contendere audeat (O najwyższej Trójcy i o wierze katolickiej i o tym, aby nikt o niej nie ośmielił się publicznie dyskutować). Analogicznie w księdze pierwszej znalazły się tytuły poświęcone heretykom (C. 1,5), apostatom (C. 1,7), Żydom (C. 1,9) i poganom (C. 1,11). Do kwestii ochrony ortodoksyjnej wiary Justynian nawiązywał ponadto w swoich Nowelach ${ }^{4}$.

Uważna lektura księgi pierwszej Kodeksu Justyniańskiego i Nowel prowadzi do wniosku, że dla Justyniana integralność ortodoksyjnej wiary, uznanej za państwową, stanowiła pierwszorzędną wartość, której należało strzec ze względu na dobro państwa i pożytek duchowy poddanych. Prewencyjną i zarazem represyjną funkcję miały w tym zakresie pełnić ustanowione sankcje majątkowe przeciwko heretykom, apostatom, poganom i Żydom, a promocyjną liczne majątkowe przywileje na rzecz instytucji i wiernych Kościoła katolickiego ${ }^{5}$.

${ }^{3}$ Zob. W. Bojarski, 'Invocatio Dei' w starożytnych zbiorach prawa, [w:] Religia i prawo karne w starożytnym Rzymie, red. A. DęBIŃski, M. KurYŁowicz, Lublin 1998, s. $15-17$.

${ }^{4}$ Nov. 5,5; Nov. 109,1; Nov. 115,3,14; Nov. 115,4,8; Nov. 123,19; Nov. 131,5; Nov. 131,13 .

5 Zdaniem A. DęBiŃSKIEGo, ,panowanie Justyniana, w historii relacji Kościół państwo, uchodzi za modelową epokę cezaropapizmu”. Zob. Tenże, Kościót i prawo rzymskie, Lublin 2008, s. 46. Por. E.H. Kaden, L'église et l'état sous Justinien, [w:] «Mémoires publiés par la Faculté de droit de Genève» 9/1952, s. 109-144; M. Simonetti, La politica religiosa di Giustiniano, [w:] Il mondo del diritto nell'epoca giustinianea: caratteri e problematiche, red. G.G. ArCHI, Ravenna 1985, s. 91-111; R. Markus, La politica ecclesiastica di Giustiniano e la Chiesa in occidente, [w:] Il mondo del diritto..., s. 113-124. 
2. POJĘCIE ORTODOKSYJNEJ WIARY, HEREZJI I APOSTAZJI

Wyrażenie fides orthodoxa (ortodoksyjna wiara), jakie odnajdujemy również w Kodeksie Justyniańskim, występuje wielokrotnie w tekstach źródłowych z okresu cesarzy chrześcijańskich ${ }^{6}$. Jego równoważnikami były wyrażenia: orthodoxa religio (ortodoksyjna religia $)^{7}$, catholica religio (religia katolicka) ${ }^{8}$, sancta fides ('́więta wiara) ${ }^{9}$, sancta religio (święta religia) ${ }^{10}$, divina religio (boska religia) ${ }^{11}$, apostolica fides (wiara apostolska) ${ }^{12}$, fides catholica (wiara katolicka) ${ }^{13}$, fides Christiana (wiara chrześcijańska) ${ }^{14}$, Christiana religio (religia chrześcijańska) ${ }^{15}$ i Christianorum fides (wiara chrześcijan) ${ }^{16}$. Pierwsze z wymienionych wyrażeń znalazło największą aprobatę ze strony cesarza Justyniana. Cesarz chętnie posługiwał się także wyrażeniami ,wiara katolicka”, „ortodoksyjna religia” i ,religia chrześcijańska”. Według niego przez wiarę określaną za ich pomocą należało rozumieć wiarę zgodną z dogmatami przyjętymi i zatwierdzonymi na czterech synodach - nicejskim, konstantynopolitańskim, pierwszym efeskim oraz chalcedońskim ${ }^{17}$.

${ }^{6}$ C. $1,1,3,3$; C. $1,1,8,25$; C. $1,3,21$; C. $1,3,27$; C. $1,3,32$ pr.; C. $1,3,32,3$; C. $1,3,32,7$; C. $1,3,33$; C. $1,3,54,9$; C. $1,3,54,10$; C. $1,4,19$; C. $1,5,8,2$; C. $1,5,10$ pr.; C. $1,5,12,4$; C. $1,5,12,18$; C. $1,5,18,4$; C. $1,7,6$; C. $1,12,6$ pr.; C. $1,55,11$.

7 C. $1,2,16$ pr.; C. 1,4,19; C. 1,5,10 pr.; C. $1,55,11$.

${ }^{8}$ C.Th. $16,6,4$ pr.; C. $1,1,2,1$.

9 C.Th. $11,39,11$; C.Th. $16,7,4$; C. $1,7,3$ pr.

10 C.Th. $9,45,5$.

11 C.Th. $15,5,5$; C.Th. $16,5,6,1$; C. 1,1,2 pr.

12 C.Th. $16,6,2$ pr.

13 C.Th. 16,1; C.Th. 16,4,3; C.Th. 16,5,6,2; C.Th. 16,5,41; C.Th. 16,5,44; C.Th. $16,6,4$ pr.; C.Th. $16,11,2$; C. 1,1 ; C. $1,1,2,1$; C. $1,1,8,25$; C. $1,1,8,30$; C. 1,3,54,9; C. $1,5,8$ pr.; C. $12,59,9$ pr.

14 C.Th. $16,8,18$; C. $1,1,4$ pr.; C. 1,1,4,1; C. $1,9,11$.

15 C.Th. 9,3,7; CS. 14 ; C. $1,1,3$ pr.; C. 1,4,6,2; C. 1,4,9,1; C. 1,7,2; C. 1,7,5.

16 C. $1,9,12,1$; C. $5,27,5$ pr.

${ }_{17}$ Nov. 115,3,14: ... non esse catholicae fidei nec in sacrosancta ecclesia communicare, in qua omnes beatissimi patriarchae una conspiratione et concordia fidem 
Natomiast herezja według Justyniana była zejściem z drogi nauki katolickiej i odmiennym od katolickiego odczuwaniem i respektowaniem Kościoła ${ }^{18}$. Heretykiem był ten, kto, będąc pierwotnie katolikiem, na skutek naiwnych argumentów przestał uznawać jakieś prawdy religii katolickiej i stracił zaufanie do Kościoła oraz jego ortodoksyjnej nauki ${ }^{19}$. Justynian traktował herezję wzorem swoich poprzedników jako crimen publicum. Należy tu przypomnieć, że status przestępstwa przeciwko państwu tak pojmowana herezja otrzymała mocą konstytucji cesarzy Arkadiusza, Honoriusza i Teodozjusza II z 22 lutego 407 roku, przywołanej i potwierdzonej w Kodeksie Teodozjańskim, w którym czytamy: ,każde przestępstwo popełnione przeciwko boskiej religii przynosi szkodę wszystkich"20.

Z badań J. Syryjczyka ${ }^{21}$ wynika, że termin ,apostata” na określenie odstępcy od wiary katolickiej w prawie rzymskim pojawia się po raz pierwszy w konstytucji Teodozjusza II i Walentyniana III z roku 426, adresowanej do Bassusa, prefekta pretorianów, przywołanej w tytule

rectissimam praedicare, et sanctas quattuor synodus, Nicaenam Constantinopolitanam Ephesinam primam et Calchedonensem amplecti seu recitare noscuntur...

${ }^{18}$ C. $1,5,2,1$; C. 1,5,18,4: ... haereses autem vocamus, quae aliter sentiunt et venerantur atque catholica et apostolica ecclesia et orthodoxa fides... (... herezjami zaś nazywamy [poglądy tych osób], które inaczej [niż wierni chrześcijanie] odczuwają i oddają cześć zarówno katolickiemu i apostolskiemu kościołowi, jak i ortodoksyjnej wierze...). A. Berger, La concezione di eretico nelle fonti giustinianee, «Rendiconti della Classe di Scienze morali, storiche e filologiche» 10.5-6/1955, s. 366, zauważa, że legislacja teodozjańska była bardziej precyzyjna w kwestii definicji heretyków niż justyniańska.

19 C. $1,5,12,4$; por. A. DęBIŃSKI, 'Sacrilegium' w prawie rzymskim, Lublin 1995, s. 168-169 przyp. 14.

${ }^{20}$ C.Th. 16,5,40,1: (Imppp. Arcadius, Honorius et Theodosius AAA. Senatori pu.) Ac primum quidem volumus esse publicum crimen, quia quod in religionem divinam conmittitur, in omnium fertur iniuriam; zob. A. DęBIŃskI, Ustawodawstwo karne rzymskich cesarzy chrześcijańskich w sprawach religijnych, Lublin 1990, s. 83 i nn.

21 J. SyrYJCZYK, Apostazja od wiary w świetle przepisów kanonicznego prawa karnego. Studium prawno-historyczne, Warszawa 1984, s. 30. 
De apostatis Kodeksu Teodozjańskiego ${ }^{22}$, a następnie w analogicznym tytule Kodeksu Justyniańskiego ${ }^{23}$.

Niezwykle ważną z punktu widzenia pojęcia apostazji i odpowiedzialności karnej za nią była konstytucja cesarzy Walentyniana II, Teodozjusza I i Arkadiusza z 11 maja roku 391, adresowana do Flawiana, prefekta pretorianów, wyłączająca z kręgu apostatów zasługujących na karę tzw. lapsi (upadłych) ${ }^{24}$. Wzorem Kościoła prawo chrześcijańskich cesarzy traktowało ich łagodniej, ponieważ mniemano, że o ich odstąpieniu od wiary przesądził nie zły zamiar, lecz ciężka bojaźńn ${ }^{25}$.

Dostrzeżenie przez wymienionych cesarzy różnicy między apostazją dobrowolną i wymuszoną było w pełni uzasadnione. Wielu bowiem chrześcijan, zwłaszcza w czasach prześladowań za Juliana Apostaty, z konieczności odstępowało od wiary i przechodziło na pogaństwo.

Ostatecznie analiza treści tytułu siódmego De apostatis księgi szesnastej Kodeksu Teodozjańskiego i tytułu siódmego De apostatis księgi pierwszej Kodeksu Justyniańskiego skłania do postawienia tezy, że chrześcijańscy cesarze rzymscy pod pojęciem przestępstwa apostazji rozumieli świadome i dobrowolne całkowite porzucenie wiary chrześcijańskiej, które następowało przez przyjęcie judaizmu lub pogaństwa. Przestępstwo apostazji nie identyfikowało się zatem z przestępstwem herezji, której istota sprowadzała się do błędnej wiary

${ }^{22}$ C.Th. 16,7,7 pr.: (Impp. Theodosius et Valentinianus AA. Basso pp.) Apostatarum sacrilegum nomen... Por. M.P. BACCARI, Gli apostati nel Codice Teodosiano, «Apollinaris» 54.3-4/1981, s. 551-557.

23 C. $1,7,4$ pr.

${ }^{24}$ Termin lapsi występujący w cytowanej konstytucji miał swoje źródło w doktrynie Kościoła katolickiego. W stosunku do apostatów przymuszonych do odstępstwa od wiary katolickiej stosował go miedzy innymi św. Ambroży. Zob. Ep. 17,4; J.P. Migne, 'Patrologiae Cursus Completus'. Series Latina, Parisiis 1878-90, s. 1002; por. J. GAudEMEt, L'Église dans l'empire romain ( $I V^{e}-V^{e}$ siècles), Paris 1958, s. 597-598.

${ }_{25}$ C.Th. 16,7,4,1 = C. 1,7,3,3: (Imppp. Valentinianus, Theodosius et Arcadius AAA. Flaviano pp.) ... Lapsis etenim et errantibus subvenitur... 
w Chrystusa ${ }^{26}$. Tym niemniej można zgodzić się z poglądem, iż każdy apostata był heretykiem, ponieważ, porzucając wiarę chrześcijańską, profanował święty sakrament chrztu, przez który został włączony do wspólnoty chrześcijan ${ }^{27}$.

\section{MAJĄTKOWE SANKCJE KARNE ZA PRZESTĘPSTWO HEREZJI}

Tytuł piąty księgi pierwszej Kodeksu Justyniańskiego zawiera kilkanaście konstytucji cesarzy chrześcijańskich z IV i V wieku, wymierzonych przeciwko różnorodnym herezjom, które Justynian uznał za groźne dla obywateli imperium rzymskiego. Pomijając cały szereg sankcji o charakterze administracyjnym, grożących za praktykowanie i głoszenie heretyckich poglądów, jak np. zakaz zamieszkiwania w miastach, zgromadzeń religijnych, nazywania miejsc zakazanych spotkań kościołami, czy sprawowania funkcji publicznych - większość z nich traktuje o majątkowych sankcjach karnych, jakie należało stosować wobec heretyków, aby, jak się wydaje, prewencyjnie zdeterminować katolików do trwania w jedności ortodoksyjnej wiary i skutecznie zapobiec szerzeniu się błędów doktrynalnych.

Pierwszą z konstytucji zamieszczonych w analizowanym tytule piątym, która podejmuje problematykę majątkowych sankcji karnych, jest konstytucja cesarzy Arkadiusza, Honoriusza i Teodozjusza II z 22 lutego 407 roku, adresowana do Senatora, prefekta miasta. Wersja tej konstytucji, jaką prezentuje C. 1,5,4, jest wersją interpolowaną. Jej poprzednia wersja znajduje się w C.Th. 16,5,40. Przede wszystkim zawiera ona, zarówno w wersji justyniańskiej, jak i teodozjańskiej, potępienie sekt donatystów i manichejczyków, które stanowiły największe zagrożenie dla porządku publicznego w imperium rzymskim, będącym wówczas, co by nie powiedzieć, katolickim państwem wy-

26 T. Mommsen, Römisches Strafrecht, Leipzig 1899, s. 603; P.M. CAMERA, 'De delictis contra Religionem in iure romano-oristiano', «Antonianum» 28.3/1953, s. 405.

${ }^{27}$ C. 1,7,3 pr.: (Imppp. Valentinianus, Theodosius et Arcadius AAA. Flaviano pp.) Ii, qui sanctam fidem prodiderint et sanctum baptisma haeretica superstitione profanaverint... (Ci zaś, którzy porzucili świętą wiarę i sprofanowali święty chrzest przez heretycki zabobon...); J. SYRYJCZYK, op. cit., s. 40-41. 
znaniowym ${ }^{28}$. Zaznaczyć wszakże należy, iż wersja justyniańska pomija mniej groźne w VI wieku herezje frygijczyków i pryscylian.

Justynian uznaje w niej wzorem swoich poprzedników każdą z wymienionych herezji za przestępstwo publiczne (publicum crimen). Swoją decyzję uzasadnia tym, że popełnia się je przeciwko boskiej religii i tym samym przynosi się szkodę wszystkim (obywatelom) ${ }^{29}$.

Karą, jaka groziła heretykom, była przede wszystkim konfiskata ich majątków na rzecz fiskusa, dokonywana z zachowaniem procedury publikacji. Wersja justyniańska nie uwzględnia jednak pierwotnej woli autorów omawianej konstytucji, by skonfiskowane dobra były oddane przez samych heretyków ich najbliższym ascendentom, descendentom i krewnym do drugiego stopnia w linii bocznej, z zachowaniem porządku dziedziczenia ustawowego, jeżeli ci nie splamili się żadną herezją $a^{30}$.

Sprawców przestępstwa herezji konstytucja ta pozbawiała zarówno prawa do wszelkich przysporzeń majątkowych i wszelkiej sukcesji (testamentowej i beztestamentowej) po kimkolwiek i pod jakimkolwiek tytułem, jak i uprawnienia do dokonywania darowizn i zawierania umów kupna-sprzedaży. Wszelkie rozporządzenia ostatniej woli zmarłych heretyków należało natomiast uważać za nieważne, bez względu na to, czy zostały wyrażone w testamencie, w kodycylu, w liście, czy w jakiś inny sposób. Ustawa wzbraniała również dostępu do spadku dzieciom zmarłego heretyka, chyba że porzuciły jego błędy ${ }^{31}$.

Dodać należy, że w świetle teodozjańskiej wersji omawianej konstytucji pretekstem do wdrożenia procedury konfiskaty mienia heretyka na rzecz cesarzy mogło być także przynajmniej przyzwolone przez bezbożnego właściciela wymierzenie kary zbiegłym niewolnikom,

28 Szerzej na ten temat zob. G.G. ArChI, Teodosio II e la sua codificazione, Napoli 1976, s. 159 i n.; L. DE Giovanni, Chiesa e Stato nel Codice Teodosiano (Saggio sul libro XVI), Napoli 1980.

${ }^{29}$ C. $1,5,4,1$; por. C.Th. 16,5,40. Zob. S. PietrinI, Sull'iniziativa del processo criminale romano (IV-V Secolo), Milano 1996, s. 60.

${ }^{30}$ C. $1,5,4,1$.

31 C. 1,5,4,3-5. 
którzy porzucili go dla wierniejszej służby Kościołowi katolickiemu ${ }^{32}$. Ów fragment interpolowana wersja justyniańska pomija. Jest to jednak logiczne, ponieważ postanawia się w niej, że tego rodzaju zbiedzy z mocy samego prawa stawali się wolni ${ }^{33}$. Takie zaś postanowienie dowodzi, że w czasach Justyniana funkcjonowała oryginalna forma wyzwolenia niewolników z mocy samego prawa ze względu na korzyść wiary, czy też, inaczej mówiąc - na podstawie przywileju wiary (privilegium fidei).

Próbę całościowego spojrzenia na kwestię różnorodności zjawiska herezji prezentuje zamieszczona w C. 1,5,5 konstytucja cesarzy Teodozjusza II i Walentyniana III z 30 maja 428 roku, adresowana do Florencjusza, prefekta pretorianów. Odnosi się ona aż do 34 herezji, spośród których wymienieni cesarze, a w ślad za nimi cesarz Justynian, uznali manicheizm za herezję najbardziej niebezpieczną i wyjątkowo szkodliwą społecznie. Justyniańska wersja tej konstytucji, podobnie zresztą jak wiele innych, nie jest tożsama z tą, jaką zna Kodeks Teodozjański ${ }^{34}$. Na skutek dokonanej interpolacji, z jej pierwotnej treści usunięto ważny z punktu widzenia niniejszego artykułu fragment nakazujący heretykom oddać Kościołowi katolickiemu swoje miejsca zgromadzeń, a zwłaszcza te, które wcześniej sami zagarnęli wypędzonym katolikom. Mniej radykalny jest także język omawianej konstytucji, być może dlatego, że w epoce justyniańskiej zmniejszył się stopień zagrożenia ze strony najbardziej aktywnych sekt. Zasadniczo nie zmienił się tylko stosunek do manichejczyków. Nawet według interpolowanej wersji manichejczycy nie mieli prawa do żadnego miejsca kultu religijnego w całym imperium. Co więcej, należało ich wypędzać z każdego miasta.

Należy podkreślić, że konstytucja, jaką znamy z C. 1,5,5, utrzymywała w mocy wszystkie wcześniejsze rozporządzenia przeciwko heretykom, zarówno te, które dotyczyły zakazu darowizn, posiadania

32 Por. C.Th. $16,5,40,6$.

33 C. $1,5,4,8$.

${ }^{34}$ C.Th. 16,5,65; L. FAlchi, La tradizione giustinianea del materiale teodosiano (CTh. XVI), «SDHI» 57/1991, s. 1 i n. 
miejsc heretyckich zgromadzeń, nazywania ich kościołami, jak i nabywania majątków spadkowych i użyczania domów prywatnych na cele kultu.

Może jedynie dziwić brak występowania w niej zakazu uprawiania prozelityzmu na szkodę Kościoła katolickiego i przeszkadzania komukolwiek w wyznawaniu ortodoksyjnej wiary, zarówno wolno urodzonemu, jak też własnemu niewolnikowi. Naruszenie tego zakazu w teodozjańskiej wersji omawianej konstytucji skutkowało wygnaniem, grzywną w wysokości dziesięciu złotych libr oraz pozbawieniem prawa do sporządzania testamentów i darowizn, przy czym katolikom groziły identyczne kary za bierne znoszenie owych wykroczeń i brak ich denuncjacji ${ }^{35}$. Fakt nieuwzględnienia go w wersji justyniańskiej nie oznaczał jednakowoż jakiejś zasadniczej zmiany frontu wobec heretyków, lecz co najwyżej stanowił jeden z zabiegów kodyfikatorów, zmierzających do lepszego usystematyzowania wszystkich zakazów i sankcji karnych.

W Kodeksie Justyniańskim aprobatę znalazła następnie konstytucja cesarzy Teodozjusza II i Walentyniana III z 3 sierpnia 435 roku, skierowana do Leoncjusza, prefekta miasta ${ }^{36}$, również dotknięta interpolacją. Potwierdza ona potępienie pism Nestoriusza na soborze efeskim, zwołanym przez Teodozjusza w dniach od 22 czerwca do 31 lipca 431 roku i nakazuje, by gorliwie ich poszukiwano, a następnie spalono na placu publicznym. Zawiera ponadto postanowienie, że ktokolwiek ośmieliłby się z nich gdziekolwiek i w jakikolwiek sposób korzystać, miał zostać ukarany konfiskatą majątku z zastosowaniem publikacji ${ }^{37}$.

Inną konstytucja, jaka została utrzymana w mocy w C. 1,5,8, jest konstytucja cesarzy Walentyniana III i Marcjana z roku 455, adresowana do Paladiusza, prefekta pretorianów, dotycząca Aleksandrii i diecezji Egiptu. Przede wszystkim zabraniała eutychistom i apollinarystom, uznanym za heretyków, wznoszenia na swoje potrzeby kościołów i klasztorów. Następnie ustanawiała sankcję w postaci konfiskaty

\footnotetext{
${ }^{35}$ C.Th. $16,5,65,4$.

${ }^{36}$ C.Th. $16,5,66$.

${ }^{37}$ C. $1,5,6,2$; por. C.Th. $16,5,66,2$.
} 
majątku (domu, posiadłości, klasztoru) - na rzecz miejscowego, partykularnego Kościoła katolickiego - ortodoksyjnych właścicieli, którym sędzia udowodnił dobrowolne udostępnienie swoich nieruchomości na nielegalne, sekciarskie zebrania. Zarządców takich włości (conductor, procurator, actor), uprzystępniających je heretykom bez aprobaty ortodoksyjnych właścicieli, należało zaś ukarać, po udowodnieniu winy, publiczną chłostą, a gdyby byli bez zarzutu, grzywną w wysokości dziesięciu złotych libr ${ }^{38}$.

Z konstytucji poteodozjańskich, które dotyczą heretyków, Justynian uznaje w swoim kodeksie jeszcze konstytucję cesarza Leona, skierowaną do Erytriusza, prefekta pretorianów. Ma ona wyraźny charakter prewencyjny. Ostrzega mianowicie katolików, że każda czynność prawna, dzięki której zbyliby oni heretykom jakąkolwiek nieruchomość z zabudowaniami kościelnymi, będzie nieważna, a pola i inne włości z kościołami i kaplicami, gdyby zostały wydane $\mathrm{w}$ ich ręce, podlegać będą konfiskacie na rzecz skarbu państwa ${ }^{39}$.

O zakazie dopuszczania do dziedziczenia zstępnych, zarówno na drodze testamentowej, jak i ustawowej oraz otrzymania przez nich jakichkolwiek innych przysporzeń majątkowych po rodzicu lub rodzicach należących do jakiejś sekty, jeżeli sami podzielaliby ich heretyckie poglądy, wzmiankuje następnie konstytucja Justyniana z 529 roku, adresowana do Demostenusa, prefekta pretorianów ${ }^{40}$. Przynosi ona także potwierdzenie wszystkich wcześniejszych konstytucji wprowadzających kary na pogan i heretyków ${ }^{41}$.

W zakres niniejszych rozważań wchodzą również ograniczające $f a$ cultatem testamenti postanowienia Nov. 115,3,14 z 1 lutego 542 roku, wydane generalnie przeciwko heretykom, a w szczególności przeciwko nestorianom i acefalom. Zgodnie z nimi nie wolno im było sporządzać testamentów, jak tylko na rzecz swoich dzieci - ortodoksyjnych chrześcijan. Jeżeli jednak żadne z dzieci nie wyznawało ortodoksyjnej
38 C. $1,5,8,4-5$.
39 C. $1,5,10$ pr. i 1 .
40 C. $1,5,19$ pr.
41 C. $1,5,19,4$. 
wiary, należało dopuścić do dziedziczenia katolickich agnatów lub kognatów. Gdyby zaś spadkodawca nie miał agnatów lub kognatów należących do Kościoła katolickiego, a był duchownym, spadek po nim w ciagu roku miał przejąć Kościół miejsca jego domicylu, a w przypadku zaniedbania ze strony Kościoła - fiskus. Gdyby natomiast taki spadkodawca był osobą świecką - majątek po nim wprost przypadał fiskusowi i stawał się integralną częścią dóbr cesarskich ${ }^{42}$.

Z 1 września 532 roku pochodzi konstytucja cesarza Justyniana I, adresowana do Jana, prefekta pretorianów, w której wspomniany prawodawca, przypominając o zakazie nabywania spadków, legatów i fideikomisów przez heretyków, rozciąga ów zakaz również na rozporządzenia ostatniej woli żołnierzy, zarówno sporządzane na mocy prawa cywilnego, jak i z zastosowaniem żołnierskiego przywileju ${ }^{43}$.

Restrykcje cesarza Justyniana dotyczyły także posagu kobiet, które na skutek wyznawanej herezji pozbawiły się wspólnoty z Kościołem katolickim. Cesarz uznał je w Nov. 109 z roku 541 za niegodne udzielonych wcześniej wszystkim kobietom przywilejów ustanowienia dla nich posagu na sposób, w jaki one sobie życzyły, nawet przez ich wcześniejszych wierzycieli oraz posiadania go bez względu na upływ czasu, jak również ustanawiania hipoteki na czasowych darowiznach otrzymanych z okazji zamążpójścia (donationes propter nuptias) ${ }^{44}$.

\section{MajątKowe SANKCJE KARNE ZA PRZESTĘPSTwO APOSTAZJI}

Tytuł siódmy księgi pierwszej Kodeksu Justyniańskiego, poświęcony apostatom, otwiera zaaprobowana przez Justyniana konstytucja cesarzy Konstancjusza II z roku 357, zaadresowana do Talassjusza, prefekta pretorianów. Ustanawia ona konfiskatę majątku na rzecz fiskusa jako karę dla katolików, którzy, porzuciwszy ortodoksyjną wiarę, przeszli na judaizm ${ }^{45}$.

\footnotetext{
42 Por. C. $1,5,10$ i Nov. $115,3,14$.

43 C. $1,5,22$.

44 Nov. 109,1.

45 C. $1,7,1$.
} 
Pierwsze sankcje za porzucenie wiary przez chrześcijan wyrażające się w przejściu na pogaństwo zostały przewidziane w konstytucji cesarzy Gracjana, Walentyniana II i Teodozjusza I z 2 maja 381 roku, adresowanej do Eutropiusza, prefekta pretorianów. W myśl jej postanowień chrześcijanie, którzy, porzucając ortodoksyjną wiarę, stawali się poganami, tracili na skutek swej apostazji uprawnienie do testowania. Co więcej, każdy ich testament podlegał unieważnieniu ${ }^{46}$. Rzecz znamienna, Justynian w swoim kodeksie nie zamieścił jednak żadnej wzmianki na temat treści tej konstytucji. Być może dlatego, że bardziej kompleksowo problem w istocie tych samych sankcji, bo w odniesieniu zarówno do apostatów przechodzących na pogaństwo, jak i na judaizm, regulowała konstytucja wymienionych wyżej cesarzy z dnia 21 maja 383 roku, adresowana do Hypacjusza, prefekta pretorianów, zamieszczona w C.Th. 16,7,3 ${ }^{47}$, a następnie w C. 1,7,2. Rzeczona konstytucja stwarzała także możliwość wniesienia do sądu w ciągu pięciu lat od śmierci testatora pozbawionego testamenti factio activa powództwa przeciwko jego testamentowi, tj. querella inofficiosi testamenti ${ }^{48}$. Skarżący musiał w tym wypadku udowodnić, że zmarły, wzgardziwszy chrześcijańską wiara, porzucił ją i zaczął praktykować kult pogański lub żydowskie obrzędy ${ }^{49}$.

Bardzo wymowna w swej treści jest następnie uznana w C. 1,7,3 konstytucja cesarzy Walentyniana II, Teodozjusza I i Arkadiusza

46 C.Th. $16,7,1$.

${ }^{47}$ C.Th. 16,7,3 pr.: (Imppp. Gratianus, Valeninianus et Theodosius AAA. ad Hypatium pp.) Christianorum ad aras et templa migrantium negata testandi licentia vindicamus admissum. Eorum quoque flagitia puniantur, qui Christianae religionis et nominis dignitate neglecta Iudaicis semet polluere contagiis... (Postanawiamy pomścić [przestępstwo apostazji] chrześcijan, którzy udają się do ołtarzy i świątyń [pogańskich], odbierając im uprawnienie testowania. Karze podlegają także haniebne czyny tych, którzy wzgardziwszy chrześcijańską religią i zaszczytnym imieniem [chrześcijan], plamią się kontaktami z Żydami...).

${ }^{48}$ C.Th. $16,7,3,1$; C. 1,7,2. Na temat querella inofficiosi testamenti, na podstawie której powód domagał się spadku, zob. E. ReNIER, Etude sur l'histoire de la 'querela inofficiosi testamenti' en droit romain, Liege 1942.

${ }^{49}$ Zob. C.Th. 16,7,3,1. Należy zauważyć, że C. 1,7,2 nie zawiera wzmianki o tym wymogu. 
z 11 maja 391 roku, skierowana na ręce Flawiana, prefekta pretorianów ${ }^{50}$. Czytamy w niej: „Ci, którzy porzucili świętą wiarę i sprofanowali chrzest przez heretyckie bałwochwalstwo, niech będą wyłączeni ze wspólnoty ze wszystkimi, wykluczeni od składania zeznań, i, jak to już wcześniej postanowiliśmy, pozbawieni zdolności do sporządzania testamentów, dziedziczenia z jakiegokolwiek tytułu i nikt nie może ich ustanowić dziedzicami" ${ }^{51}$.

Podobnie w świetle utrzymanej w mocy konstytucji cesarzy Teodozjusza II i Walentyniana III z 7 kwietnia 426 roku, jaką otrzymał do stosowania Bassus, prefekt pretorianów, apostaci byli pozbawieni z chwila porzucenia wiary prawa do dokonywania darowizn i sporzadzania testamentów. Nie wolno im także było zezwalać na omijanie prawa przez pozorną sprzedaż swoich dóbr ${ }^{52}$.

Ponadto Justynian zaaprobował treść konstytucji wymienionych cesarzy z 438 roku, adresowanej do Florencjusza, prefekta pretorianów, i zamieścił ją w swoim kodeksie. Zgodnie z jej treścią tego, który pod przymusem lub namowami nakłonił swojego niewolnika lub człowieka wolno urodzonego do porzucenia wiary chrześcijańskiej i wstąpienia do grzesznej sekty i obrządku, należało ukarać śmiercią, a jego majątek skonfiskować 53 .

5. WYDZIEDZICZENIE JAKO FORMA REPRESJI WOBEC POGAN, APOSTATÓW I HERETYKÓW

W kontekście szykan w postaci sankcji omówionych w poprzednim punkcie, jakie w prawie justyniańskim spotykały pogan, heretyków i apostatów, nie dziwi fakt, że Justynian uczynił brak łączności z Kościołem i uznawania jego dogmatów jedną z przyczyn wydzie-

50 Wcześniej zamieszczona w C.Th. 16,7,4. Wnikliwej analizy okoliczności wydania tej konstytucji i jej treści dokonał U. VINCENTI, La legislazione contro gli apostati data a Concordia nell'anno 391 (CTh. 16.7.4-5), «SDHI» 61/1995, s. 399-412.

${ }^{51}$ C. $1,7,3$ pr.

${ }_{52}$ C.Th. $16,7,7,1=$ C. $1,7,4,1$.

${ }^{53}$ C. $1,7,5$. 
dziczenia. Przepisy Noweli 115, która jako pierwsza wprowadziła zamknięte katalogi przyczyn wydziedziczenia, odnosiły się zarówno do descendentów, jak i ascendentów.

Tytuł trzeci Noweli 115 zawierał katalog czternastu przyczyn wydziedziczenia descendentów. Ostatnia z nich dotyczyła herezji. W myśl Nov. 115,3,14 osoby, które zostały ochrzczone i wychowane w religii katolickiej i na skutek przystapienia do jakiejś sekty zaprzestały praktyk w ortodoksyjnej wierze i utrzymywania wspólnoty z Kościołem katolickim, mogły być wydziedziczone przez wstępnych ${ }^{54}$. Wydaje się, że skoro apostazja oznaczała całkowite porzucenie wiary chrześcijańskiej, tym bardziej wstępni mogli wydziedziczyć descendentów, jeśli stali się oni apostatami ${ }^{55}$. Podmiotem uprawnionym do wydziedziczenia zstępnego z powodu herezji był wyłącznie ascendent trwający w wierze katolickiej i utrzymujący więzi z Kościołem. Jeżeli sam ascendent nie trwał w wierze katolickiej, to nie mógł czynić zarzutu niewdzięczności swojemu zstępnemu. Tak samo, jeżeli nie wychował zstępnego w wierze katolickiej.

Dla Justyniana herezja, rozumiana jako forma odstępstwa od doktryny Kościoła katolickiego, choć wymieniona jako ostatnia w katalogu przyczyn wydziedziczenia, stanowiła przyczynę największej niewdzięczności descendentów (maxime causa ingratos) wobec ortodoksyjnych ascendentów.

${ }^{54}$ Nov. 115,3,14: Si quis de praedictis parentibus orthodoxus constitutus senserit suum filium vel liberos non esse catholicae fidei nec in sacrosancta ecclesia communicare, in qua omnes beatissimi patriarchae una conspiratione et concordia fidem rectissimam praedicare et sanctas quattuor synodus, Niceanam Costantinopolitanam Ephesinam primam et Chalcedonensem, amplecti seu recitare noscuntur, licentiam pro hac maxime causa ingratos eos et exheredes in suo scribere testamento... (Jeżeli któryś ze wspomnianych ascendentów, nastawiony ortodoksyjnie, byłby przeświadczony, że jego syn lub dzieci nie wyznają wiary katolickiej i nie utrzymują wspólnoty ze świętym Kościołem, w którym wszyscy najświętsi patriarchowie jednomyślnie i zgodnie głoszą najprawdziwszą wiarę i uznają, czyli propagują cztery święte synody Nicejski, Konstantynopolitański, pierwszy Efeski i Chalcedoński; zezwala im się na to, żeby z tej największej przyczyny opisali ich w swoim testamencie jako niewdzięcznych i wydziedziczyli...).

55 J. SYRYJCZYK, op. cit., s. 40-41. 
Tytuł czwarty Noweli 115 zawiera z kolei katalog ośmiu słusznych przyczyn wydziedziczenia wstępnych. Tu także ostatnia z nich odnosi się do herezji. W tym przypadku jednak Justynian nie upatruje przyczyny wydziedziczenia tylko w fakcie odstępstwa od wiary katolickiej w formie herezji lub apostazji i nieutrzymywaniu w konsekwencji pełnej wspólnoty z Kościołem katolickim, lecz rozciąga tę przyczynę także na stan faktyczny pozostawania przez wstępnych w opozycji do wiary katolickiej przez brak jej przyjęcia ${ }^{56}$. Tak więc wstępni także, jeżeli w ogóle nie byli katolikami, mogli być wydziedziczeni. Oznacza to, że stanowiący podstawę wydziedziczenia wstępnych brak świadectwa wiary katolickiej względem potomstwa mógł być skutkiem albo tego, że wstępni nigdy nie byli katolickiego wyznania, albo popadli w herezję lub apostazję.

Należy podkreślić, że wydziedziczenie ze względu na herezję, apostazję, a także ze względu na brak przynależności do Kościoła, było $\mathrm{w}$ istocie znaczącym instrumentem polityki religijnej Justyniana służącym umocnieniu wiary katolickiej, ponieważ w razie nawrócenia się wydziedziczonych na ortodoksyjną wiarę i powrócenia do pełnej jedności z Kościołem katolickim, przyczyna wydziedziczenia dezaktualizowała się i przysługiwało im prawo do należnego działu spadkowego.

Wydziedziczając ze wskazaniem tej przyczyny, testator unikał podważenia swojego testamentu, spełniając zasadę sui heredes instituendi sunt vel exheredandi, i zapobiegał dziedziczeniu ustawowemu.

\section{GWARANCJE ZABEZPIECZEŃ MAJĄTKOWYCH DLA DZIECI TRWAJĄCYCH W ORTODOKSYJNEJ WIERZE I PORZUCAJACCYCH HERETYCKIE POGLĄDY}

Prawo justyniańskie brało w ochronę i uprzywilejowywało dzieci, które otrzymały chrzest w Kościele katolickim i nigdy nie odstąpiły od

${ }^{56}$ Nov. 115,4,8: Si quis de praedictis liberis orthodoxus constitutus senserit suum parentem vel parentes non esse catholicae fidei, haec et in eorum persona tenere quae supra de parentibus iussimus (Jeżeli któryś ze wspomnianych zstępnych nastawiony ortodoksyjnie byłby przeświadczony, że jego wstępny lub wstępni nie wyznają wiary katolickiej, to wszystko, co wyżej odnośnie do wstępnych [było postanowione], i w ich przypadku zachować nakazujemy). 
ortodoksyjnej wiary, mimo że ich rodzice (jedno z nich lub oboje) byli wyznawcami innej religii. Takie dzieci na mocy konstytucji Justyniana z 529 roku, adresowanej do Demostenusa, prefekta pretorianów, zostały dopuszczone do sukcesji majątkowej porodzicach, zarówno testamentowej, jak i beztestamentowej oraz uprawnione do tego, by otrzymywać od nich wszelkiego rodzaju darowizny i inne przysporzenia majątkowe mortis causa ${ }^{57}$.

W tej samej konstytucji Justynian nakazał nieprawowiernym rodzicom nie tylko właściwie rozporządzić na korzyść ortodoksyjnych dzieci na wypadek śmierci, lecz także zobowiązał ich do należytej dbałości o zaspokojenie codziennych potrzeb potomstwa, ustanowienie posagu dla córek i wnuczek oraz darowizn z okazji zawarcia małżeństwa dla synów i wnuków, proporcjonalnie do swojej zamożności ${ }^{58}$.

Następnie w Nov. 115,3,14 przypomniał generalną zasadę, że rodzicom, którzy pozostają poza wspólnotą Kościoła katolickiego na skutek wyznawania heretyckich poglądów, nie wolno ustanawiać dziedzicami innych osób, jak tylko swoje dzieci wyznające ortodoksyjną wiarę, a gdyby ich nie mieli, innych agnatów lub kognatów, którzy byliby ortodoksyjnej wiary. Gdyby jednak okazało się, że część spośród ich dzieci wyznaje ortodoksyjną wiarę, a część odseparowała się od Kościoła katolickiego, nakazał, aby cały majątek pozostały po rodzicach przypadł tylko tym dzieciom, które pozostały wierne Kościołowi katolickiemu, chociażby rodzice postapili wbrew postanowieniom niniejszej konstytucji ${ }^{59}$.

Justynian, podzielając stanowisko cesarzy Arkadiusza, Honoriusza i Teodozjusza II, zawarte w konstytucji z 22 marca 407 roku, adresowanej do Senatora, prefekta miasta, w kwestii zdolności testamentowej, pomijając innych heretyków, zachował w swoim Kodeksie przepis, według którego jakikolwiek wyraz ostatniej woli rodziców wyznających manicheizm był z mocy samego prawa nieważny, bez względu na to, czy została ona ujawniona w testamencie, czy w kody-

\footnotetext{
57 C. $1,5,19$ pr.

58 C. $1,5,19,3$.

59 Nov. $115,3,14$.
} 
cylu lub w jakikolwiek inny sposób ${ }^{60}$. W ślad za Teodozjuszem II nie pozwolił również, aby dzieci takich ludzi dziedziczyły po nich, chyba że odstapiłyby od błędów swoich rodziców (nisi a paterna pravitate discesserint $)^{61}$.

Należy zatem stwierdzić, że pozbawienie sukcesji majątkowej dzieci manichejczyków było warunkowe. Z zamieszczonego w C. 1,5,4,6 i w C.Th. 16,5,40,5 zdania: delicti enim veniam paenitentibus damus - wynika jednak, że samo formalne porzucenie heretyckich poglądów nie było wystarczające. Nawrócone na ortodoksyjną wiarę dzieci musiały ponadto przejawić oznaki pokuty i zwrócić się z prośbą do cesarza o przywrócenie im prawa do dziedziczenia po zmarłych rodzicach.

W przywołanej wcześniej Nov. 115 Justynian określił z kolei zasady postępowania z potomkami, którzy po uprzednim podziale majątku spadkowego między dzieci wyznające ortodoksyjną wiarę, powrócili do jedności wiary, czyli nawrócili się. Zarządził mianowicie, aby ortodoksyjni bracia lub siostry, którzy skorzystali z uprzywilejowanego prawa przyrostu, zwrócili nawróconym należną im część, w stanie, w jakim znajdowała się ona w momencie, w którym ci drudzy zostali jej pozbawieni z racji wyznawanej herezji. Nawróceni nie mieli zatem prawa żądać odszkodowania od ortodoksyjnego rodzeństwa z tytułu pobieranych pożytków z ich działów spadkowych przez okres, gdy oni pozostawali poza wspólnotą Kościoła katolickiego. Co więcej, w oczekiwaniu na nawrócenie ich braci i sióstr, Justynian zakazał ortodoksyjnemu rodzeństwu alienacji majątku, który mógł przypaść im, gdyby ci nawrócili się ${ }^{62}$. Tym samym omawiana konstytucja dawała jasno do zrozumienia pozostającym przy heretyckich poglądach dzieciom, że warto się nawrócić.

\footnotetext{
${ }^{60}$ C. $1,5,4,5$; C.Th. $16,5,40,5$.

${ }^{61}$ C. $1,5,4,6$; C.Th. $16,5,40,5$.

${ }^{62}$ Nov. 115,3,14.
} 
7. PRZYWILEJE DUCHOWNYCH I ZAKONNIKÓW ORAZ KOŚCIOŁÓW, MONASTERÓW I POBOŻNYCH DZIEŁ KoŚCIOŁA KATOLICKIEGO W DZIEDZINIE PRAWA SPADKOWEGO I MAJĄTKOWEGO

Korzystając z cesarskiej władzy, Justynian uznał za prawnie wiążące między innymi stanowisko imperatorów Leona I i Anathemiusa, wyrażone w konstytucji skierowanej do prefekta pretorianów w Konstantynopolu z roku 470. Zgodnie z jego treścia, władze publiczne zostały zobligowane do bezdyskusyjnego uznawania za ważne wszelkich oświadczeń woli dotyczących jakichkolwiek przysporzeń majątkowych na rzecz Kościoła katolickiego, zarówno w drodze czynności prawnej inter vivos, jak i mortis causa, pod warunkiem, że dokonano ich z zachowaniem przepisanej prawem formy. Expressis verbis wymieniono $\mathrm{w}$ tym stanowisku następujące czynności prawne umożliwiające Kościołowi sukcesję uniwersalną: sporządzenie przez darczyńcę jakiegokolwiek prawnie uznanego testamentu, także testamentu nunkupacyjnego albo kodycylu. Kościół mógł także partycypować w sukcesji syngularnej, jeżeli darczyńca ustanowił na jego rzecz legat, fideikomis, darowiznę mortis causa albo wyraził swoją wolę darowania czegoś ze swojego majątku w jakimś innym oświadczeniu ostatniej woli, przez które, wydaje się, należało rozumieć polecenie na wypadek śmierci (ultimo arbitrio) ${ }^{63}$. Raz darowanego Kościołowi majątku (tak nieruchomości, jak i ruchomości) nikomu nie wolno było w żaden sposób uszczuplać czy alienować. Zakaz w tym względzie dotyczył zarówno biskupów, ekonomów diecezjalnych, jak i innych duchownych, którzy, używając słów omawianego postanowienia, winni byli integralnie zachowywać prawa (majątkowe) kościelne, by ów majątek wieczyście służył Kościołowi, skoro ten jako matka religii i wiary jest wieczny $^{64}$.

Justynian utrzymał również $\mathrm{w}$ mocy postanowienie imperatorów Teodozjusza II i Walentyniana III, skierowane do Taurusa, prefekta pretorianów, w 434 roku. W myśl tego postanowienia, jeżeli prezbiter

\footnotetext{
${ }^{63}$ C. $1,2,14,1$.

${ }^{64}$ C. $1,2,14,1-2$.
} 
lub diakon, diakonisa, subdiakon lub inny duchowny jakiegokolwiek stopnia, albo mnich czy kobieta, która poświęciła się życiu w odosobnieniu, zmarli, nie sporządziwszy żadnego testamentu i jednocześnie nie przeżyliby ich rodzice obojga płci, dzieci lub inni agnaci lub kognaci uprawnieni do dziedziczenia ustawowego, albo żona, pozostawione przez nich dobra miały przypaść kościołowi lub monasterowi, do którego oni przynależeli, z wyjątkiem tych dóbr, które zgodnie z przepisami prawa należały się po ich śmierci ich panom, patronom albo kurii. Tym niemniej kościoły i monastery zachowywały prawo do skarg o wydanie rzeczonych dóbr, jeżeli przypadkiem wyżej wymienieni zostaliby uwolnieni od ciążących na nich zobowiązań, bądź na skutek zawartych umów, bądź też wniesienia innych powództw kościelnych ${ }^{65}$.

W C. 1,3,54,5, dokładnie mówiąc, w konstytucji adresowanej do Jana, prefekta pretorianów, cesarz zadbał następnie o interesy kandydatów do stanu duchownego i zakonnego, zakazując rodzicom przeszkadzania im w tych zamiarach i grożenia im wydziedziczeniem z powodu rzekomej niewdzięczności. Tam też nakazał rodzicom ustanowić w testamencie, sporządzonym w jakiejkolwiek legalnej formie, odpowiedni zachowek i zachęcał, aby oni dali dzieciom nawet więcej. Gdyby się jednak tak zdarzyło, że rodzice nie wyraziliby swojej ostatniej woli ani w testamencie, ani w inny dozwolony prawem sposób, zobowiązywał adeptów do stanu duchownego lub zakonnego do domagania się swojego ustawowego działu spadkowego, zarówno wtedy, gdy byliby jedynymi dziedzicami ustawowymi, jak i wówczas, gdyby dziedziców ustawowych było wielu ${ }^{66}$.

Dodać należy, że Justynian, respektując postanowienia kanonów kościelnych, uznawał prawo monasterów do majątków swoich mnichów, którzy złożyli śluby, jak się wydaje, wieczyste. O ile mnich przed złożeniem ślubów rozporządził swoim majątkiem inter vivos lub sporządził testament, monaster nie mógł niczego sobie rościć. Jednakże na skutek złożenia profesji, a w szczególności ślubu ubóstwa, mnich tracił testamenti factio activa. Problem powstawał, jeżeli mnich złożył

\footnotetext{
${ }^{65}$ C. $1,3,20$ pr. $i 1$.

${ }^{66}$ C. $1,3,54,5$.
} 
profesję, a miał dzieci, żonę lub wierzycieli, a nie sporządził uprzednio testamentu, czy w inny sposób wcześniej nie zabezpieczył swoich najbliższych i nie zaspokoił swoich wierzycieli.

W Nov. 5,5, ustosunkowując się do tego przypadku, powodowany potrzebą zabezpieczenia majątkowego najbliższych krewnych i współmałżonka, Justynian postanowił, aby w miejsce mnicha pozbawionego prawa testowania, w przypadku jego śmierci, decydowały za niego przepisy prawa. Monastery z nabytego tą drogą majątku zostały zobowiązane do przekazania tytułem darowizny dzieciom, które nic nie otrzymały od ojca przed złożeniem przez niego profesji zakonnej (ani darowizny przedślubnej, ani posagu), równowartość zachowku albo, jeżeli coś już z tego majątku od swojego ojca otrzymały, odpowiedni suplement uzupełniający ustawowo należny im zachowek. Przy tym monastery wzbogacone o majątek zmarłego mnicha winny były uszanować prawa żony, tzn. zwrócić jej posag i zabezpieczenie majątkowe przyrzeczone jej w umowie małżeńskiej na wypadek śmierci męża i vice versa, jak i spłacić jego lub jej długi wobec wierzycieli ${ }^{67}$.

Według Nov. 123,19 jakikolwiek majątek, który stał się własnością duchownych (prezbiterów, diakonów, subdiakonów, kantorów i lektorów) i będący w ich posiadaniu, należało traktować na równi z peculium castrense. Zgodnie z prawem duchowni mogli dysponować nim tak, jak chcieli. Mogli oni także rozporządzać nim testamentowo, chociażby znajdowali się pod władzą ojcowską, z tym jednak zastrzeżeniem, że ich dzieci, a w ich braku ich rodzice, powinni byli otrzymać należny im zachowek ${ }^{68}$.

W Nov. 131,15 cesarz zezwolił biskupom na rozporządzenia testamentowe na rzecz kogokolwiek, jeżeli dotyczyły one dóbr nabytych przez nich na własność przed konsekracją biskupią czy też uzyskanych tytułem spadku po krewnych do czwartego stopnia. Dobra nabyte przez nich inną drogą zarezerwowane zostały kościołom, w których zostali ustanowieni biskupami, o ile nie skonsumowano ich na pożytek kościelny lub na dzieła pobożności. Te same normy polecił także

\footnotetext{
67 Nov. 5,5, pr.

68 Nov. 123,19; por. C. 1,3,33.
} 
stosować wobec administratorów (zarządców) sierocińców, hospicjów dla biednych i obłożnie chorych, szpitali, domów chorych i starców, a także innych rektorów. Gdyby zaś biskupi lub administratorzy umarli bez testamentu i bez ustawowych dziedziców, nakazał, by dziedziczenie ustawowe miało zastosowanie wyłącznie do kościołów, w których zostali ustanowieni ${ }^{69}$.

O specyficznym spojrzeniu cesarza Justyniana na własność kościelną świadczą również rozporządzenia zawarte w Nov. 131,5. Przede wszystkim mocą tej konstytucji majątki kościelne i domy będące w jurysdykcji kościelnej zostały zwolnione od wszelkich ciężarów i nadzwyczajnych podatków na rzecz miast. Co więcej, legislator zobowiązał miasta do naprawy dróg, mostów i obiektów kościelnych, które znajdowały się w ich obrębie. Zwolnił także kościoły od podatku od przysporzeń majątkowych, które nabyły lub nabędą z majątków kurialnych ${ }^{70}$.

Przedstawione powyżej przepisy, zawarte w ustawodawstwie cesarza Justyniana, dowodzą ponad wszelką wątpliwość, że ten skądinąd wybitny reformator prawa rzymskiego traktował prawo nad wyraz instrumentalnie w kwestii ochrony wiary katolickiej, zwanej ortodoksyjna. Potwierdzają one stosowanie przez niego w sprawach wyznaniowych metody tzw. „kija i marchewki”. Z jednej strony zawierają bowiem rozliczne sankcje majątkowe przeciwko heretykom i apostatom, z drugiej zaś przewidują przywileje majątkowe dla samego Kościoła i dla pozostających w jedności z Kościołem katolickim oraz materialne zachęty do powrotu na jego łono ${ }^{71}$.

Przepisy te oddają ducha epoki justyniańskiej, który daleki był od poszanowania wolności jednostki ludzkiej w zakresie sumienia i wyznania.

${ }^{69}$ Nov. 131,13,1-3; por. C. 1,3,33.

70 Nov. 131,5.

71 Według B. DumÉzILA, Chrześcijańskie korzenie Europy. Konwersja $i$ wolność w królestwach barbarzyńskich od V do VIII wieku, Kęty 2008, s. 76, od czasów Kodeksu teodozjańskiego „kolejni cesarze woleli dążyć do konwersji swych poddanych na religię państwową jakby okrężną drogą, poprzez faworyzowanie tych, którzy przyjmowali ją dobrowolnie, i niesprzyjanie tym, którzy jej nie przyjmowali”. 
Ich analiza wykazuje daleko idącą koherentność z przepisami wyznaniowymi wcześniejszych cesarzy chrześcijańskich, a zwłaszcza $\mathrm{z}$ ustawodawstwem cesarza Teodozjusza $\mathrm{II}^{72}$.

\section{Protection of the Orthodox ReLigion IN THE LEGISLATION OF JUSTINIAN I}

\section{Summary}

The protection of the Orthodox religion was one of the priorities in Justinian's life and activities. However, his religious policy was not very different from that of previous Christian emperors. The aim of this article is to show that Justinian's policy was more a result of tendencies in the legal protection of Orthodoxy which had already developed in the postConstantinian age, in other words Justinian only reinforced existing regulations; and likewise his legislation to eradicate heresy and apostasy was similar to earlier provisions.

Justinian used legal measures for the protection of the True Faith in an immensely instrumental way. On the one hand he maintained and introduced numerous material sanctions against heretics and apostates; on the other hand he prescribed material advantages for the Orthodox Church and those in communion with her. There were also material incentives for those who returned to the Church. The article shows that Justinian's measures followed the same line as the religious regulations introduced by previous Christian emperors, especially Theodosius II.

72 Por. E. Dovere, Législation théodosienne «de fide»: le choix conciliaire (années 435-449), [w:] Empire chrétien et Église aux IVe et Viècles. Intégration ou "concordat»? Le témoignage du Code Théodosien, red. J-N. GuINOT, F. Richard, Paris 2008, s. 98. 